\title{
New Study of Mgo Nps in Drilling Fluid to Reduce Stick-Slip Vibration in Drilling System
}

\author{
Saifalden Y. Alssafar and Faleh H. M. Al-Mahdawi
}

Petroleum Engineering Department, University of Baghdad

\begin{abstract}
Stick-slip is kind of vibration which associated with drilling operation in around the bottom hole assembly (BHA) due to the small clearance between drill string \& the open hole and due to the eccentric rotating of string. This research presents results of specific experimental study that was run by using two types of drilling mud (Fresh water Bentonite \& Polymer), with/without Nanoparticle size materials of $\mathrm{MgO}$ in various ratios and computes the rheological properties of mud for each concentration [Yield point, plastic viscosity, Av, PH, filter loss (30 min), filter cake, Mud Cake Friction, Friction Factor]. These results then were used to find a clear effects of Nanoparticle drilling mud rheology on stick - slip strength by several perspectives through a special "Torque and Drag" software which simulate the torque amount expected on BHA during drilling a vertical well in different conditions using real drilling string design that usually used in Iraqi oil fields. Thus to mitigate or to prevent stick-slip and cure the sequence events that could happen to both of drilling string and the well, i.e. Bit/BHA wear, pipe sticking, borehole instability and low Rate of penetration. Our study concluded that there are good reduction in the torque from (2031lb-ft) to (1823lb-ft) using polymer mud and torque reduction from $(4000 \mathrm{lb}-\mathrm{ft})$ to $(3450 \mathrm{lb}-\mathrm{ft})$ using Fresh Water Bentonite, these results do not include any breaking in the satisfactory range of other mud rheology.
\end{abstract}

Keywords: stick - slip motion, drilling mud, Nano particles, $\mathrm{MgO}$ and drill string vibration

Received on 13/01/2019, Accepted on 25/02/2019, published on 30/06/2019

https://doi.org/10.31699/IJCPE.2019.2.7

\section{1- Introduction}

It is a usual routine that problems occur while drilling a well, even if we reviewed the well plan carefully. For example, in areas in which similar drilling practices are used hole problems may have been reported were no such problems existed previously in offset wells because formations are nonhomogeneous. Therefore, several wells near each other may have different geological conditions. [1], [2]

The failures of a drill string have increased obviously in the last 10 to 15 years due to the use of directional drilling modeling and complex models with expensive downhole tools which make vibration monitoring and controlling is a key of drilling optimization, and have become a serious issue resulting in substantial cost effective. Therefore, detection and control of drill string vibrations have become an area of considerable interest. [3]

Three main types of vibration frequently occur (individually or together) during drilling formation, (torsional vibration, axial vibration and lateral vibration). Over limited vibration can cause drill string failure, poor directional tendency, premature bit failure, stalling of the top drive or rotary table, hole enlargement, MWD tool failure, and Bit /Stabilizer / tool joint wear[4].

Torsional vibrations are often classified as one of the most damaging models of vibration when downhole tools called stick-slip Phenomenon [5], [6].

\section{2- Aim of This Study}

In this Study, anew work is acted to find out the relationship between the using of ( $\mathrm{Nano}-\mathrm{MgO})$ materials in drilling mud and stick slip vibration during drilling in different concentrations.

To achieve real results the test has been ran in two major types of drilling mud; freshwater Bentonite (FWB) Mud and Polymer Mud, to cover the drilling muds for both of shallow and deep wells.

\section{3- Methodology}

$\mathrm{MgO}$ is usually manufactured by calcination of magnesium carbonates. In contrast to expansive additives, the reactivity of $\mathrm{MgO}$ is influenced by the manufacturing process. In comparison with other materials $\mathrm{MgO}$ exhibit a considerably higher free enthalpy, thus a higher reactivity, even in the dead-burnt state (manufacture at a temperature above $1600^{\circ} \mathrm{C}$ ), while $\mathrm{MgO}$ nanoparticles are prepared by microwave-assisted synthesis using magnesium acetate, where $\mathrm{MgO}$ Nano-powders is synthesized using microwave plasma torch.[7]

It is clearly noticed that Nano fluids made by Nano $\mathrm{MgO}$ show specific properties such as a high tendency for adsorption, where $\mathrm{MgO}$ increases the effect of attraction forces in comparison with repulsion forces which results in fine fixation [8], [9]. 


\subsection{Sonication System}

Ultrasonic system consists of 3 major components: Generator, Converter and probe (Horn).

The Generator transforms AC line power to electrical energy with high frequency by providing high voltage pulses of energy at a frequency of $20 \mathrm{kHz}$ that drives a piezoelectric by Converter, the probe's tip expands and contracts longitudinally, this will lead to cavitation in the liquid and violent collapse of microscopic bubbles during rapid vibration. The collapse of many of cavitation bubbles releases a huge energy in the cavitation field. This feature is a keypad, which allows the user to adjust the sonication parameters as per test requirements [10].

\subsection{Ultrasonic}

Dispersion of nanoscale materials has become dependent on ultrasonic methods. Even with chemical dispersing agents, were to provide access to these agents onto material surfaces, ultrasonic is required.

In usual dispersion runs, sonication takes $12-36 \mathrm{hrs}$. in order to ensure a good dispersion in an appropriate solvent.

\subsection{Ultra-Sonic Device (Elma)}

Ultrasonic device made for multipurpose duties: remove chlorine from water, kill Bacterial cells, remove and recover ammonia from industrial waste water move and recover ammonia from industrial wastewater [10] as shown in Fig. 1 below:

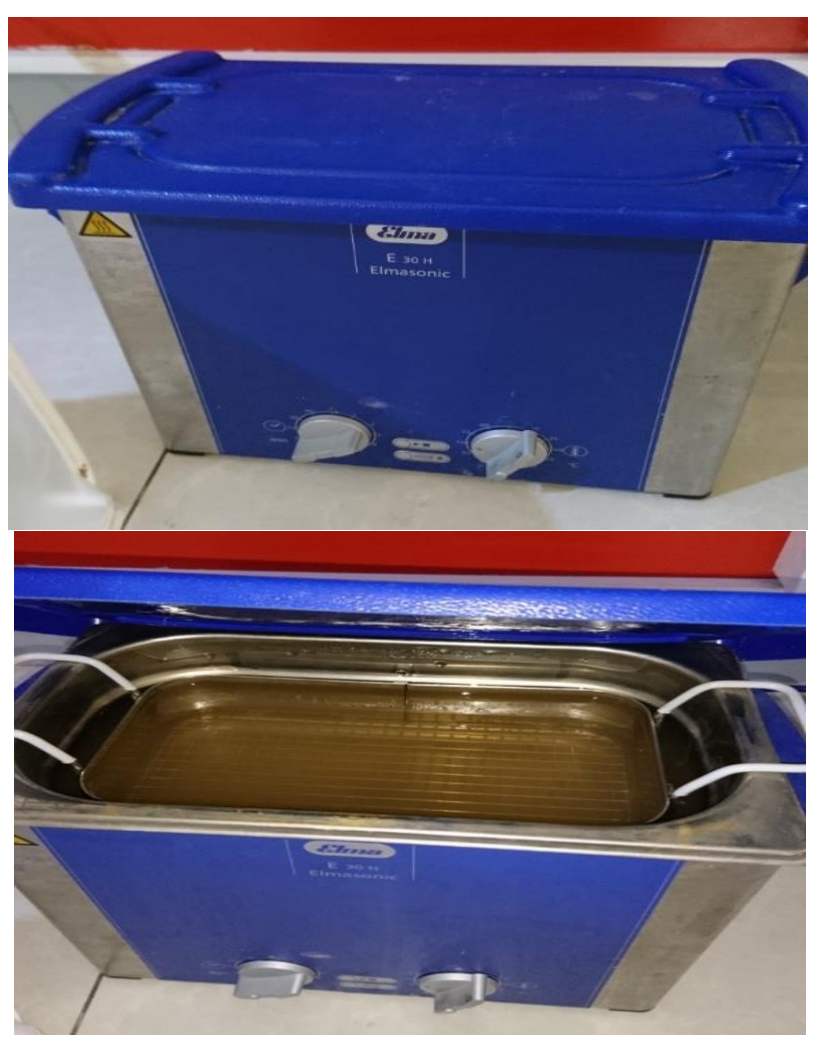

Fig. 1. Elma ultrasonic device

\subsection{Mud Lubricity Tester}

In this study, generally use the lubricity meter to measure the COF or the coefficient of friction (Baroid lubricity coefficient) between the test ring and block [11].

The lubricity test represents (simulates) drill pipe rotation against downhole surfaces, using a constant load of 150 inch-pounds (600psi) is applied using a torque arm.

The lubricity tester is regularly used to evaluate and predict the impact made by a drilling fluid additive on friction.

The following coefficients are recognized as acceptable value:

1- CoF For water-based mud, a coefficient $<0.2$

2- CoF For oil-based mud, a coefficient $<0.1$

3- CoF For ester-based mud, a coefficient $<0.1$

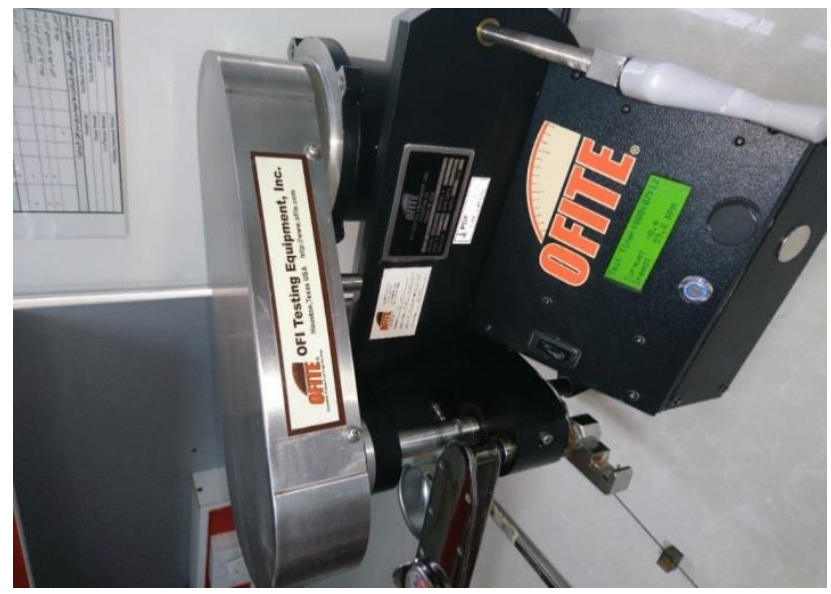

Fig. 2. Ofite EP and LUBRICITY TESTER

The OFITE EP and Lubricity tester is used to measure and evaluate the lubricating quality of drilling fluids, predict wear rates of mechanical parts in known fluid systems and provide data to assess the type and quantity of lubricating additives that may be required.

The following Calculations is required: Correction Factor $=34$ Meter (32 to 36)

\section{Lubricity Coefficient $=$ Meter Reading $\times$ Correction Factorl00}

Percent of Torque Reduction $=A-B A \times 100$

Where: $\mathrm{A}=$ Torque reading of untreated mud, $\mathrm{B}=$ Torque reading of treated mud

And from viscometer:

Plastic viscosity

$(P V), c P=\theta 600-\theta 300$

Yeild Point (YP), Ib/100ft2= $\theta 300-P V$

Apparent Viscosity (AV), $c P=\theta 600 / 2$ 
Gel strength, 10 second, $\mathrm{Ib} / 100 \mathrm{ft} 2=$ the maximum dial deflection after $10 \mathrm{sec}$

Gel strength, 10 Minute, $\mathrm{Ib} / 100 \mathrm{ft} 2=$ the maximum dial deflection after $10 \mathrm{Min}$.

\subsection{Torque and Drag Software}

Using the results of the lab test we took the friction factor and put it in a special Torque and drag software made by a global company to simulate a drilling job and find out Torque on the bit.

\section{a. Torque and Drag Software assumption}

The drilling model was build using parameters of IDC56 to drill vertical well, $121 / 4$ " hole section, $\mathrm{WOB}=28$ $30 \mathrm{Klb}$. (WOB $=12 \mathrm{Klb}$. For FWB mud where this mud used in shallow depth), RPM $=40$ and fixed friction factor of $0.25 \mathrm{ft}-\mathrm{lb}$ between drilling string and 13 3/8" casing. The drilling Bit and BHA designed as follow:

Table 1. BHA Design

\begin{tabular}{|c|c|c|c|c|c|c|}
\hline Item & Description & $\mathrm{OD}$ & ID & Weight & Length & Cum. Lengt \\
\hline \# & & (in) & (in) & (lbpf) & (m) & (m) \\
\hline 1 & PDC & 8.000 & 3.500 & 138.52 & 0.44 & 0.44 \\
\hline 2 & Near-Bit Stabilizer with FV & 8.000 & 3.000 & 147.22 & 2.31 & 2.75 \\
\hline 3 & MWD Directional + Gamma & 8.000 & 4.000 & 128.48 & 9.90 & 12.65 \\
\hline 4 & $1 \times 8$ " Drill Collar & 8.000 & 2.750 & 150.70 & 9.14 & 21.79 \\
\hline 5 & Integral Blade Stabilizer & 8.000 & 3.000 & 147.22 & 2.16 & 23.95 \\
\hline 6 & PBL Circulating Sub & 8.000 & 3.250 & 143.03 & 2.00 & 25.95 \\
\hline 7 & $5 \times 8$ " Drill Collar & 8.000 & 2.750 & 150.70 & 45.70 & 71.65 \\
\hline 8 & 8" Sledgehammer Jar & 8.120 & 2.750 & 132.58 & 6.66 & 78.31 \\
\hline 9 & $1 \times 8$ " Drill Collar & 8.000 & 2.750 & 150.70 & 9.14 & 87.45 \\
\hline 10 & X-Over Sub & 8.000 & 2.875 & 149.18 & 0.78 & 88.23 \\
\hline 11 & $2 \times 63 / 4 "$ Drill Collar & 6.750 & 2.750 & 101.50 & 18.28 & 106.51 \\
\hline 12 & $15 \times 5 "$ HWDP & 5.000 & 3.000 & 49.30 & 140.70 & 247.21 \\
\hline 13 & 5" DP & 5.000 & 4.276 & 21.92 & 9.00 & 256.21 \\
\hline
\end{tabular}

\section{4- Experimental Work}

This work aims to improve the rheological properties of drilling mud by reducing the friction of the mud with less filtration plus thin mud cake.

Drilling fluids have prepared with two major types of mud (FWB \& Polymer mud) using varies Nano $\mathrm{MgO}$ ratio.

All experiments tests conducted under laboratory conditions, and then the mud hot rolled by heating for four hours in about 250 degree Fahrenheit and retested again.
Table 2. Polymer Mud Materials

\begin{tabular}{llll}
\hline Composition & Unit & Blank & Mixing Time \\
\hline Drill Water & cc & 280.4 & - \\
Sodium Chloride & gr & 61.3 & $5 \mathrm{~min}$ \\
Potassium Chloride & gr & 11.6 & $5 \mathrm{~min}$ \\
Caustic Soda & gr & 1 & $5 \mathrm{~min}$ \\
Soda Ash & gr & 1.5 & $5 \mathrm{~min}$ \\
Starch & gr & 12 & $15 \mathrm{~min}$ \\
PAC LV & gr & 1 & $15 \mathrm{~min}$ \\
Xanthan & gr & 0.5 & $15 \mathrm{~min}$ \\
Limestone $(50-75 \mu)$ & gr & 87.6 & $20 \mathrm{~min}$ \\
\hline
\end{tabular}

Table 3. FWB Mud Materials

\begin{tabular}{lllll}
\hline Composition & Unit & Blank Sample & Mixing Time \\
\hline Drill Water & cc & 350 & - & \\
Bentonite & gr & 22.5 & 20 & in \\
\hline
\end{tabular}

\subsection{Sample Preparation}

a. Procedure of Nano-MgO dispersion

1- Nano MgO powder was mixed in Distilled water and subjected to Ultrasonic Bath.

2- Surfactant for efficient dispersion of nanoparticles was mixed in Distilled water and subjected to Ultrasonic Bath too.

3- In the end, both solutions were merged and put in the Ultrasonic Bath for 7-8 hours.

4- We made five samples (cups), the first cup without $\mathrm{MgO}$ (as a blank) then adding 0.3, 0.6, 0.9, $1.5 \mathrm{gm}$ of $\mathrm{MgO}$ consequently.

5- Different concentrations of this Nano-colloidal solution added to the drilling fluid system as following:

$\begin{array}{ll}\text { I. } 280.4 \mathrm{CC} \text { of polymer mud. } & \text { II. } 350 \mathrm{CC} \text { of }\end{array}$ FWB.

b. Prepare polymer mud

Preparing was made based on the following table and mixed them by multimixer Fann 9B:

Table 4. Composition of Polymer Mud

\begin{tabular}{llll}
\hline Composition & Unit & Blank & Mixing Time \\
\hline Drill Water & $\mathrm{Cc}$ & 280.4 & - \\
Sodium Chloride & $\mathrm{Gr}$ & 61.3 & $5 \mathrm{~min}$ \\
Potassium Chloride & $\mathrm{Gr}$ & 11.6 & $5 \mathrm{~min}$ \\
Caustic Soda & $\mathrm{Gr}$ & 1 & $5 \mathrm{~min}$ \\
Soda Ash & $\mathrm{Gr}$ & 1.5 & $5 \mathrm{~min}$ \\
Starch & $\mathrm{Gr}$ & 12 & $15 \mathrm{~min}$ \\
PAC LV & $\mathrm{Gr}$ & 1 & $15 \mathrm{~min}$ \\
Xanthan & $\mathrm{Gr}$ & 0.5 & $15 \mathrm{~min}$ \\
Limestone $(50-75 \mu)$ & $\mathrm{Gr}$ & 87.6 & $20 \mathrm{~min}$ \\
\hline
\end{tabular}


1- Adding Nano material (different Concentration) to blank of polymer mud and mix for $20 \mathrm{~min}$.

2- Measure viscosity by Rotational Viscometer Model OFITE 800 ( Based on the attached procedure) at $120^{\circ} \mathrm{F}$

3- Put prepared mud in hot roll for evaluating rheological properties in downhole situation at $250^{\circ} \mathrm{F}$ during 4 hrs.

4- After hot roll, measure viscosity at $120^{\circ} \mathrm{F}$ by rotational viscometer model OFITE 800

5- Measure filtrate volume by API Filter Press model Fan 300series (based on mentioned procedure) at room temperature and 100 psi pressure work.

6- Evaluate lubricity factor by EP/ Lubricity tester (based on mentioned procedure)

c. Preparing Bentonite Mud

The preparing was made based on the following table then aged in hot roll:

Table 5. FWB Mud Materials

\begin{tabular}{llll}
\hline Composition & Unit & Blank Sample & Mixing Time \\
\hline Drill Water & cc & 350 & - \\
Bentonite & gr & 22.5 & $20 \mathrm{~min}$ \\
\hline
\end{tabular}

1- Aging prepared mud in room temperature for $18 \mathrm{hrs}$.

2- Adding Nano material to prepared mud in the required concentration and mixing by a multi mixer at $20 \mathrm{~min}$.

3- Measure viscosity at $120^{\circ} \mathrm{F}$ by rotational viscometer Model OFITE 800 (Based on the mentioned procedure)

4- Measure filtrate volume by API Filter Press model Fan 300series (based on the attached procedure) at room temperature and 100 psi pressure work.

5- Evaluate the lubricity factor by EP/ Lubricity tester (based on attached procedure).

\section{d. Preparing Nano Material}

Preparing Nano Material for all experimental work can be concluded as follow:

1. Add Nano material to water and disperse it in water by ultrasonic for 1 hour.

2. Add prepared Nano solution to surfactant and disperse them for $7 \mathrm{hrs}$ by ultrasonic ( this is final Nano solution)

3. Add final Nano solution to polymer mud in during mixing based on required concentration for 20 minutes.

\section{5- Results and discussion}

\subsection{Polymer mud test with Nano $\mathrm{MgO}$ additives}

Mud Rheology changes after adding Nano $\mathrm{MgO}$ to $280.4 \mathrm{cc}$ of polymer Mud by various concentrations as shown in Table 6

Table 6. Mud Rheology parameters

\begin{tabular}{|c|c|c|c|c|c|}
\hline Rheology & -------- gm & $0.3 \mathrm{gm}$ & $0.6 \mathrm{gm}$ & $0.9 \mathrm{gm}$ & $1.5 \mathrm{gm}$ \\
\hline AV & 21.5 & 24 & 24 & 35.5 & 36.5 \\
\hline RPM 600 & 43 & 48 & 48 & 71 & 73 \\
\hline RPM 300 & 26 & 30 & 28 & 43 & 46 \\
\hline PV & 17 & 18 & 20 & 28 & 27 \\
\hline YP & 9 & 12 & 8 & 15 & 19 \\
\hline RPM 200 & 19 & 22 & 21 & 31 & 33 \\
\hline RPM 100 & 12.5 & 13.5 & 13 & 19 & 20 \\
\hline RPM 6 & 3.5 & 3.5 & 3 & & 5 \\
\hline RPM 3 & 2.5 & 3 & 2.5 & 5 & 4 \\
\hline GEL $10 \mathrm{~s}$ & 3 & 4 & 3 & 4 & 5 \\
\hline GEL $10 \mathrm{~min}$ & 4 & 5 & 4 & 5 & 6 \\
\hline $\mathrm{pH}$ & 12.21 & 10.87 & 11.24 & 11.11 & 10.98 \\
\hline API FL, cc & 2.2 & 2.7 & 2.3 & 3 & 2.8 \\
\hline Settlement & yes & No & No & No & No \\
\hline Filter cake & $1 / 32$ & $1 / 32$ & $1 / 32$ & $1 / 32$ & $1 / 32$ \\
\hline Foam & No & No & No & No & No \\
\hline $\begin{array}{l}\text { Water } \\
\text { Torque } \\
\text { Reading }\end{array}$ & 33.7 & 34.4 & 34.3 & 36.0 & 35.0 \\
\hline $\begin{array}{l}\text { Mud Torque } \\
\text { Reading }\end{array}$ & 20.1 & 20.0 & 19.9 & 19.6 & 21.2 \\
\hline $\begin{array}{l}\text { Lubricity } \\
\text { Factor }\end{array}$ & 0.2028 & 0.19767 & 0.1973 & 0.1851 & 0.2059 \\
\hline $\begin{array}{l}\text { Torque } \\
\text { Reduction }\end{array}$ & - & 0.5 & 0.9 & 2.4 & - \\
\hline $\begin{array}{l}\text { Mud Cake } \\
\text { Friction (KF) }\end{array}$ & 0.2046 & 0.2268 & 0.16578 & 0.18323 & 0.25303 \\
\hline
\end{tabular}




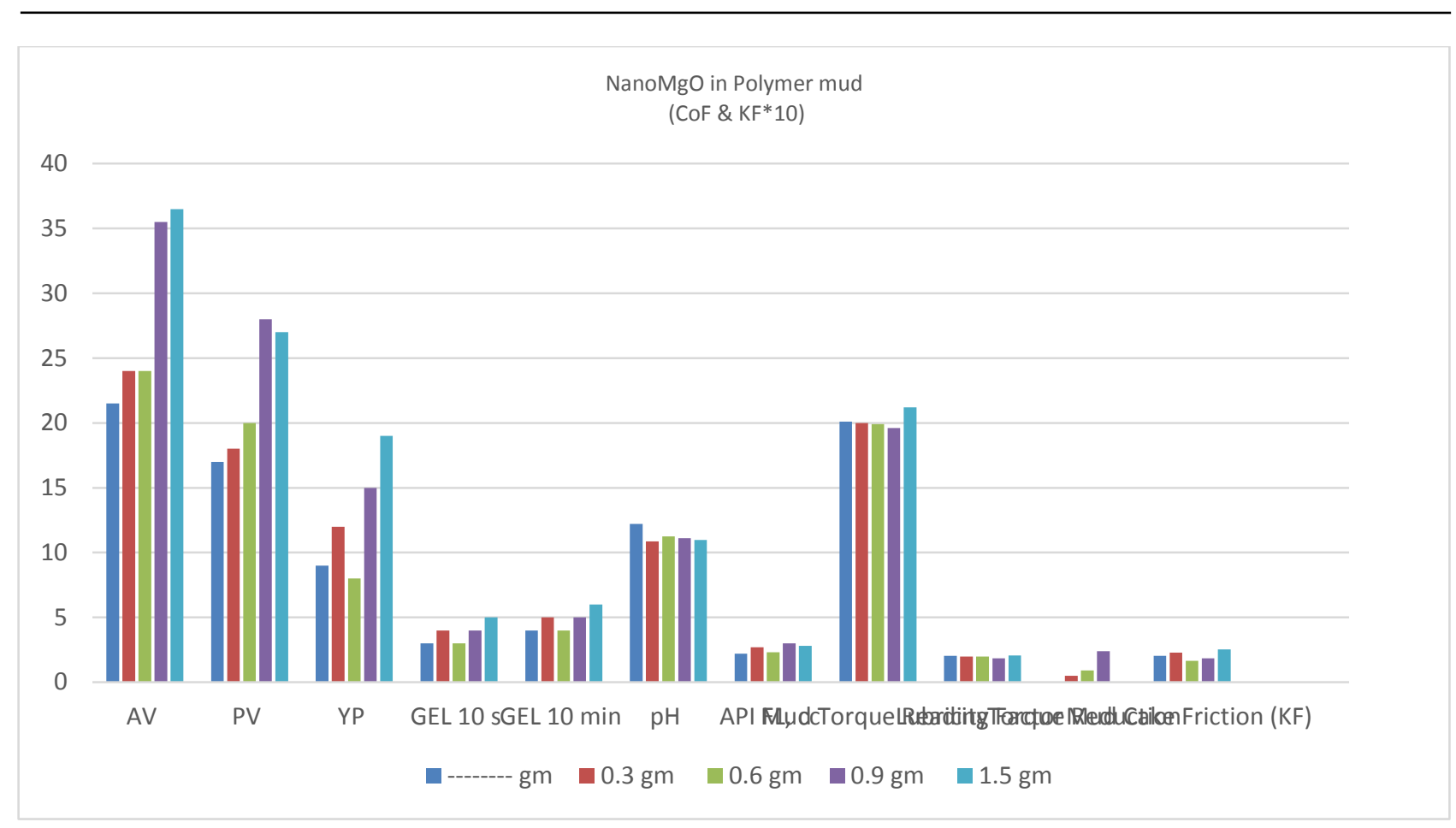

Fig. 3. Polymer mud with different MgO NPs concentrations

In Fig. 3, both Mud cake friction and Lubricity factor multiplied by 10 to clarify the change for review because their amount is too small. The diagram of Test 7 illustrated that the $\mathrm{MgO}$ concentration of $0.9 \mathrm{gm}$ in polymer mud is the most affected with regards to torque reduction with the amount " 0.1851 " of $\mathrm{CoF}$. At the same time the test of 0.9 concentration has no significant changes in other mud rheology except PV which recorded (26) where its higher than the Pv at blank and (0.3 gm) tests, as per Nanomaterials are solid structure so higher $\mathrm{PV}$ is typical results.

We can also notice YP 0.9 gm test is higher than the previous two tests but still in the allowable range to raise cutting with no formation damage.

In Table 7 Friction Mud Rheology changes after adding Nano $\mathrm{MgO}$ to $280.4 \mathrm{cc}$ of polymer Mud by various concentrations.

Table 7. CoF, KF with Torque Reduction

\begin{tabular}{llllll}
\hline Rheology & $\begin{array}{l}------- \\
\text { gm }\end{array}$ & $0.3 \mathrm{gm}$ & $0.6 \mathrm{gm}$ & $0.9 \mathrm{gm}$ & $1.5 \mathrm{gm}$ \\
\hline $\begin{array}{l}\text { Lubricity } \\
\text { Factor }\end{array}$ & 0.2028 & 0.19767 & 0.1973 & 0.1851 & 0.2059 \\
$\begin{array}{l}\text { Torque } \\
\text { Reduction }\end{array}$ & - & 0.5 & 0.9 & 2.4 & - \\
$\begin{array}{l}\text { Mud Cake } \\
\begin{array}{l}\text { Friction } \\
(\mathrm{KF})\end{array}\end{array}$ & 0.2046 & 0.2268 & 0.16578 & 0.18323 & 0.25303 \\
\hline
\end{tabular}

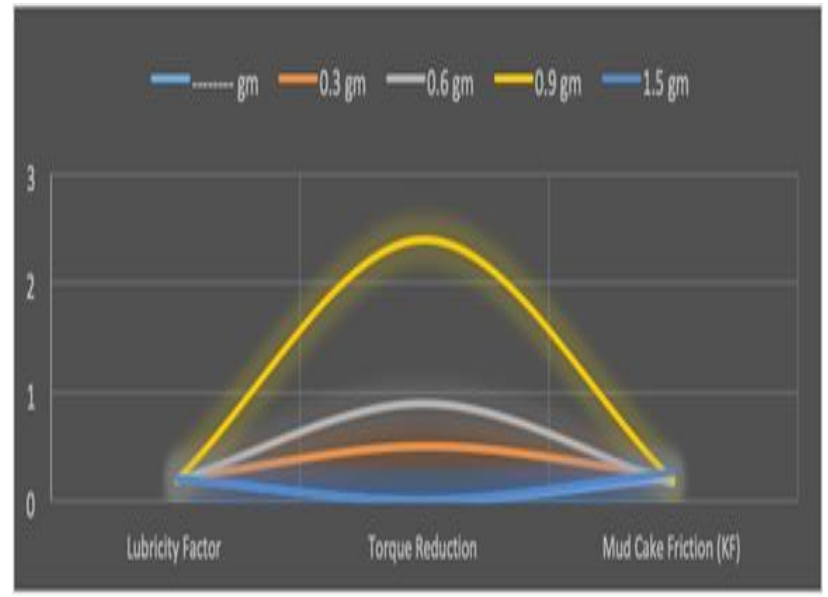

Fig. 4. CoF, KF and TORQUE reduction with related to $\mathrm{MgO}$ NPs additives in polymer

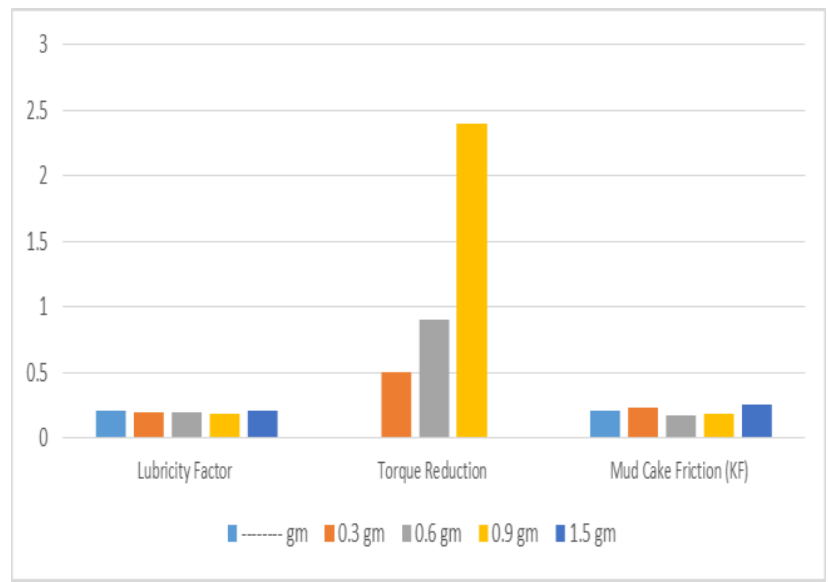

Fig. 5. CoF \& Torque reduction \& KF of five tests in polymer 
Table 8. magnitude of $\mathrm{CoF}$ with $\mathrm{MgO}$ concentration

\begin{tabular}{llllll}
\hline Rheology & $\begin{array}{l}------- \\
\text { gm }\end{array}$ & $0.3 \mathrm{gm}$ & $0.6 \mathrm{gm}$ & $0.9 \mathrm{gm}$ & $1.5 \mathrm{gm}$ \\
\hline Lubricity & 0.2028 & 0.19767 & 0.1973 & 0.1851 & 0.2059 \\
Factor & & & & & \\
\hline
\end{tabular}

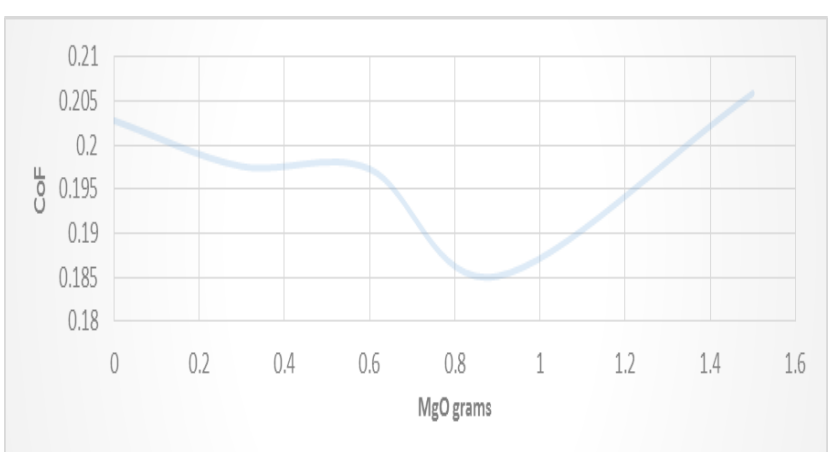

Fig. 6. $\mathrm{MgO}$ consentration\& $\mathrm{CoF}$ in polymer

In Fig. 4, Fig. 5 \& Fig. 6, it was clear that the 0.9 gm of Nano $\mathrm{MgO}$ had got the best $\mathrm{CoF}$ (lowest value) that led to decline in torque reading. However, the $\mathrm{CoF}$ and Lubricity factor had risen dramatically when the Nano concentration increased more than 0.9 gm. In addition, there is improvement in $\mathrm{CoF}$ between 0.6 to $0.9 \mathrm{gm}$ but noticed stability in $\mathrm{CoF}$ in between 0.3 to $0.6 \mathrm{gm}$. in another hand although there was $\mathrm{CoF}$ decreasing when $0.3 \mathrm{gm}$ added, but not as fall as the test of $0.9 \mathrm{gm} \mathrm{MgO}$.

In Table 9 the recorded data of torque software regarding Lubricity Factor changes with tests

Table 9. CoF and Torque reading data

\begin{tabular}{|c|c|c|c|c|c|}
\hline Rheology & gm & $0.3 \mathrm{gm}$ & $0.6 \mathrm{gm}$ & $0.9 \mathrm{gm}$ & $1.5 \mathrm{gm}$ \\
\hline $\begin{array}{l}\text { Lubricity } \\
\text { Factor }\end{array}$ & 0.2028 & 0.19767 & 0.1973 & 0.1851 & 0.2059 \\
\hline $\begin{array}{l}\text { Torque } \\
\text { reading }\end{array}$ & 2031 & 1963 & 1950 & 1823 & 2050 \\
\hline
\end{tabular}

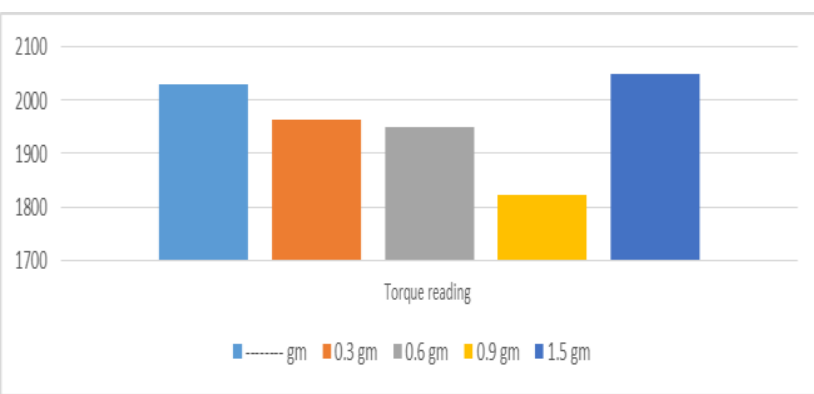

Fig. 7. Polymer \& MgO Torque software reading

From Fig. 8 \& Fig. 9, general in the blank test the software reads $4000 \mathrm{ft}-\mathrm{lb}$ and start decreasing by adding Nano $\mathrm{MgO}$ until getting its best amount in this lab tests, then refers back to 4000 in concentration Nano $\mathrm{MgO}$ of $1.5 \mathrm{gm}$. So using Nano - MgO more than (1) gm per 280.4 $\mathrm{CC}$ of polymer mud should be avoided because of it sharply higher the friction factor and mud torque amount.

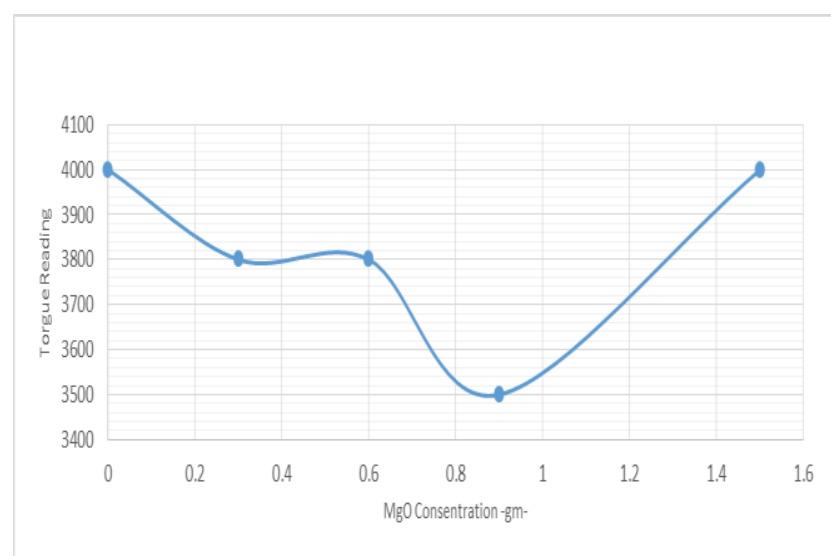

Fig. 8. Polymer\& mgo torque reading on software

The best result recorded in the test was $0.9 \mathrm{gm} \mathrm{MgO}$, however there was a little high $\mathrm{AV}$ and $\mathrm{Pv}(\mathrm{AV}=35.5 \&$ pv =28). And that due to the loos of other Nano benefits and maybe $0.9 \mathrm{gm}$ or above cannot be used when plastic viscosity is restricted in certain drilling problems expected. Therefore, the same restriction with regards to the limitation of pump pressure and/or ECD (Equivalent Circulating Density) then lead to using low AV (where, $\mathrm{AV}=$ shear stress/shear rate),so it will require higher pressure.

\subsection{Fresh Water Bentonite Mud Test With Nano Mgo Additives}

Using five cup tests consist of FWB and Nano $\mathrm{MgO}$ in different concentrations we got the results in Table $\mathbf{1 0}$.

Table 10. Mud Rheology changes after adding Nano MgO to $350 \mathrm{cc}$ of FWB Mud by various concentrations

\begin{tabular}{|c|c|c|c|c|c|}
\hline Rheology@120 F & Blank & $0.3 \mathrm{gm}$ & $0.6 \mathrm{gm}$ & $0.9 \mathrm{gm}$ & $1.5 \mathrm{gm}$ \\
\hline$\overline{\mathrm{AV}}$ & 19 & 20 & 21 & 33.5 & 42 \\
\hline RPM 600 & 38 & 40 & 42 & 67 & 84 \\
\hline RPM 300 & 35 & 35 & 39 & 62 & 79 \\
\hline PV & 3 & 5 & 3 & 5 & 5 \\
\hline YP & 32 & 30 & 36 & 57 & 74 \\
\hline RPM 200 & 33 & 37 & 38 & 62 & 76 \\
\hline RPM 100 & 30 & 35 & 37 & 59 & 72 \\
\hline RPM 6 & 25 & 33 & 34 & 56 & 66 \\
\hline RPM 3 & 24 & 33 & 33 & 55 & 65 \\
\hline GEL $10 \mathrm{~s}$ & 24 & 35 & 35 & 46 & 61 \\
\hline GEL $10 \mathrm{~min}$ & 25 & 37 & 38 & 52 & 66 \\
\hline $\mathrm{pH}$ & 9.18 & 11.40 & 11.23 & 11.26 & 11.25 \\
\hline API FL, cc & 14 & 14.3 & 16.4 & 17.0 & 15.2 \\
\hline Settlement & No & No & No & No & No \\
\hline Filter cake & 4/32" & 4/32" & $5 / 32 "$ & $5 / 32 "$ & $4 / 32 ”$ \\
\hline Foam & No & No & No & No & No \\
\hline $\begin{array}{ll}\text { Water } & \text { Torque } \\
\text { Reading } & \end{array}$ & 35.5 & 34.5 & 34.8 & 35.9 & 33.9 \\
\hline $\begin{array}{ll}\text { Mud } & \text { Torque } \\
\text { Reading } & \end{array}$ & 44.3 & 36.3 & 33.4 & 39.9 & 37.0 \\
\hline Lubricity Factor & 0.4243 & 0.3577 & 0.3266 & 0.3779 & 0.3711 \\
\hline Torque Reduction & - & 18.05 & 24.06 & 9.93 & 16.48 \\
\hline $\begin{array}{l}\text { Mud Cake } \\
\text { Friction (KF) }\end{array}$ & 0.69 & 0.0959 & 0.1483 & 0.1919 & 0.1745 \\
\hline
\end{tabular}




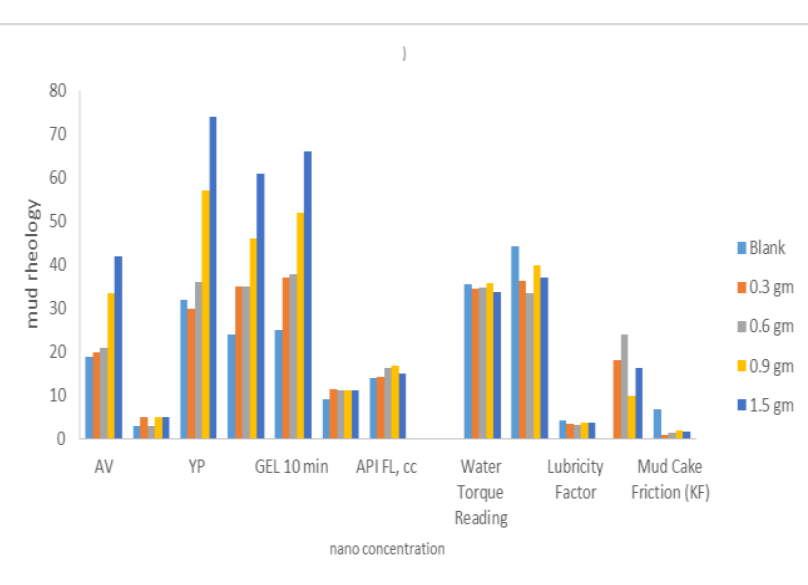

Fig. 9. Nano MgO in FWB (Lubricity Factor \& Mudcake Friction*10)

In Fig. 9 Both Mud cake friction and Lubricity factor multiplied by 10 to make it clear for review because their amount are too small.

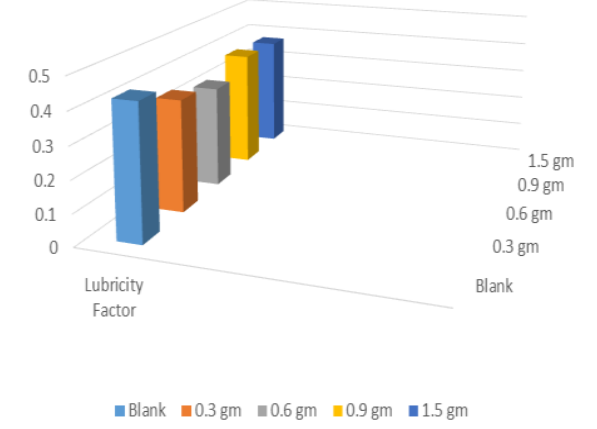

Fig. 10. Lubricity Factor (Nano MgO in FWB)

Table 11. CoF \& Torque and drag software reading

\begin{tabular}{llllll}
\hline Rheology & $\begin{array}{l}------- \\
\mathrm{gm}\end{array}$ & $0.3 \mathrm{gm}$ & $0.6 \mathrm{gm}$ & $0.9 \mathrm{gm}$ & $1.5 \mathrm{gm}$ \\
\hline $\begin{array}{l}\text { Lubricity } \\
\begin{array}{l}\text { Factor } \\
\text { Torque }\end{array}\end{array}$ & 0.4243 & 0.3577 & 0.3266 & 0.3779 & 0.3711 \\
reading & 4000 & 3500 & 3450 & 3580 & 3560 \\
\hline
\end{tabular}

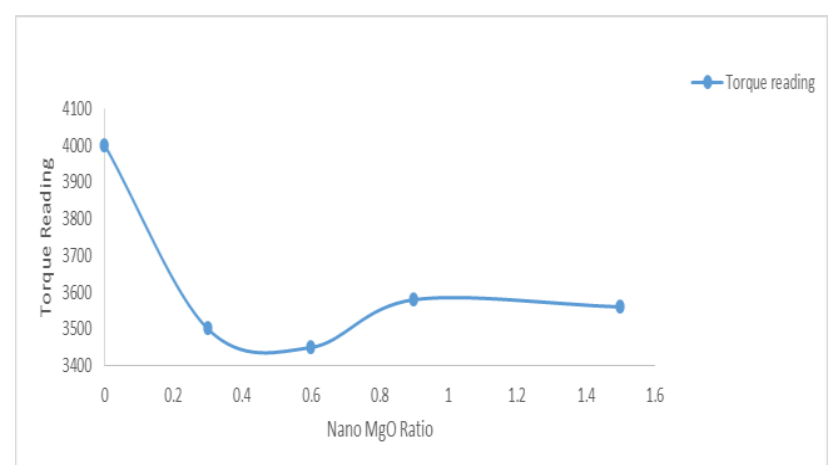

Fig. 11. Sofy ware torque reading in FWB with $\mathrm{MgO}$
By Fig. 11 we can find that Nano $\mathrm{MgO}$ additives reduced the expected downhole torque by more than 1500 $\mathrm{ft}-\mathrm{lb}$ in the concentration of $0.6 \mathrm{gm}$. and noticed a clear curve retrograded since the first $\mathrm{Nano} \mathrm{MgO}$ was added to explain the perfect acting of that Nanoparticles to FWB, then to records its best Torque reduction at concentration of $0.6 \mathrm{gm}$.

In $\mathrm{MgO}$ concentration between $0.6-0.9$ Torque goes high but still lower than it amount before adding $\mathrm{MgO}$, because of the nanoparticles of $\mathrm{MgO}$ has good effects on that mud lubricity. In the concentration of $1.5 \mathrm{gm}$ there is a little drop in torque which may indicate that will continue drop with adding $\mathrm{MgO}$ proportionally, however it will be cost effect and will raise other mud rheology i.e. GEL and PV.

\section{6- Conclusion \& Recommendations}

The following are concludes the experimental results overall:

1- In polymer mud lubricity factor dropped from 0.2 to be 0.185 when we increased $\mathrm{Nano} \mathrm{MgO}$ from zero to 0.9 gm gradually by the tests then $\mathrm{CoF}$ starts increasing again with more Nano $\mathrm{MgO}$.

2- Even though it was a minimal decrease in $\mathrm{CoF}$ with Nano additives, but it succeeds to change torque reading from $2031 \mathrm{lb}-\mathrm{ft} .$. to $1823 \mathrm{lb}-\mathrm{ft} . .$. which lead to avoid $12.5 \%$ of stick-slip vibration probability.

3- No changes were noticed in the other mud rheology except increasing in plastic viscosity due to Nano particles, so we highly recommend using Nano $\mathrm{MgO}$ as additives in drilling companies working in Iraq, especially in forecast projects no more vertical wells as much as deviated and horizontal wells which stick and slip as commonly occurs.

4- Nano $\mathrm{MgO}$ performs better rheology results with FWB mud where CoF dropped $(0.42 \Longrightarrow 0.32)$, with a clear drop in Torque reading (4000 $\Longrightarrow$ 3450).

5- The other rheology parameters were normal and acceptable to be used, therefore we recommend using Nano $\mathrm{MgO}$ in drilling fluid to mitigate stick-slip phenomenon, in Nano ratio of $1.73 \mathrm{~kg}$ per one cubic meter of mud.

Finally some of the important recommendations supposed to be in mined by future researchers:

1- Re-run the experimental work using different $\mathrm{MgO}$ Nano concentrations of the same Nanomaterials to detect any sensitive in mud rheology.

2- Choose another type of drilling muds like oil-based mud, salt mud, emulsion mud and KCL mud that used in oil fields to explore the Nano-particles effects.

3- Making a special device (similar to a drilling rig in small scale) consist of a small Bit, BHA and source of WOB with rotating advanced by torque sensors, to simulate drilling a hole and evaluate the real stick slip vibration changes with regards to adding different Nanoparticles types \& weight ratio. 


\section{Acknowledgment}

Our sincere appreciation goes to Dr. Faleh M. H. ALMahdawi whose contribution and constructive criticism has pushed me to expend the kind of efforts to make this work as original as it can be. Our grateful to all of those with whom we have had the pleasure to work during this and other related projects.

\section{Nomenclatures \& Abbreviations}

$\begin{array}{ll}\text { AV } & \text { Apparent Viscosity } \\ \text { CoF } & \text { Coefficient of friction } \\ \text { FF } & \text { Friction factor } \\ \text { hrs. } & \text { hours } \\ \text { IDC } & \text { Iraqi drilling company (Rig } \\ \text { BHA } & \text { Bottom Hole Assembly } \\ \text { NP } & \text { Nano Particle } \\ \text { NPs } & \text { Nano Particles } \\ \text { PV } & \text { Plastic Viscosity, cp } \\ \text { ROP } & \text { Rate of Penetration } \\ \text { FW } & \text { Fresh water Bentonite } \\ \text { YP } & \text { Yield Point, Ib/100ft2 } \\ \text { CP } & \text { cent poise } \\ \gamma & \text { Shear Rate, sec-1 } \\ \tau & \text { Shear Stress, Ib/100ft2 } \\ \mu p & \text { Plastic Viscosity, cp } \\ \tau_{0} & \text { Shear Stress at Yield Point, } \\ \tau_{1} & \text { Ib/100ft2 } \\ \tau 2 & \text { Shear stress at lower shear rate } \\ & \text { Shear stress at higher shear rate }\end{array}$

\section{References}

[1] A. Kyllingstad and G. W. Halsey, "A Study of Slip/Stick Motion of the Bit," SPE Drill. Eng., vol. 3, no. 4, pp. 369-373, 1988.

[2] M. I. Abdulwahab, S. Thahab, and A. H. Dhiaa, "Experimental Study of Thermophysical Properties of TiO2 Nanofluid", ijcpe, vol. 17, no. 2, pp. 1-6, Jun. 2016.

[3] Y. Q. Lin and Y. H. Wang, "New Mechanism in Drillstring Vibration," Offshore Technol. Conf., 1990.

[4] B. A. Abdulmajeed and N. S. Majeed, "Study and Analysis of Concentric Shell and Double Tube Heat Exchanger Using Tio 2 Nanofluid," Iraqi J. Chem. Pet. Eng., vol. 18, no. 4, pp. 15-23, 2017.

[5] T. V Aarrestad and H. Blikra, "Torque and Drag: Key Factors in Extended-Reach Drilling," IADC/SPE Drill. Conf., no. SPE 27491, pp. 547-552, 1994.

[6] N. Majeed and D. Naji, "Synthesis and Characterization of Iron Oxide Nanoparticles by Open Vessel Ageing Process", ijcpe, vol. 19, no. 2, pp. $27-$ $\underline{31, \text { Jun. } 2018 .}$
[7] F. H. M. Al-Mahdawi and K. Saad, "Enhancement of Drilling Fluid Properties Using Nanoparticles", ijcpe, vol. 19, no. 2, pp. 21-26, Jun. 2018.

[8] B.-Q. Xu, J.-M. Wei, H.-Y. Wang, K.-Q. Sun, and Q.M. Zhu, "Nano-MgO: novel preparation and application as support of $\mathrm{Ni}$ catalyst for $\mathrm{CO} 2$ reforming of methane," Catal. Today, vol. 68, no. 1-3, pp. 217-225, 2001.

[9] N. Jafariesfad, Y. Gong, M. R. Geiker, and P. Skalle, "Nano-Sized $\mathrm{MgO}$ with Engineered Expansive Property for Oil Well Cement Systems," SPE Bergen One Day Semin., 2016.

[10] G. T. Caneba, C. Dutta, V. Agrawal, and M. Rao, "Novel Ultrasonic Dispersion of Carbon Nanotubes," J. Miner. Mater. Charact. Eng., vol. 09, no. 03, pp. 165-181, 2010.

[11] $\underline{\text { K. Slater and A. Amer, "New Automated }}$ Lubricity Tester Evaluates Fluid Additives, Systems and Their Application," pp. 1-8, 2013. 


\section{دراسة حديثة عن تأثيراضافة مادة النانو MgO الى طين الحفر لتقليل ظاهرة الالتصاق والانزلاق(stick-slip) خلال عملية حفر الابار.}

الخلاصة

ظاهرة الالتصاق والانزلاق هي احد انواع الاهتزازات التي تحدث اثثاء عمليات الحفر حول مجموعة رأس البئر

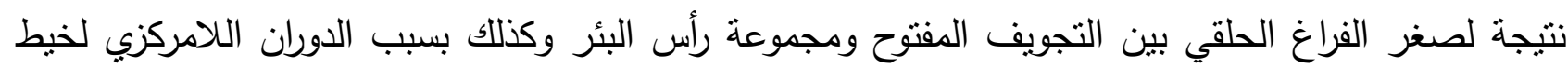
الحفر اثثاء الحفر. في هذا البحث استعراض لنتائج مختبرية باستخدام نوعين رئيسيين من طين الحفر وذلك باضافة النانو

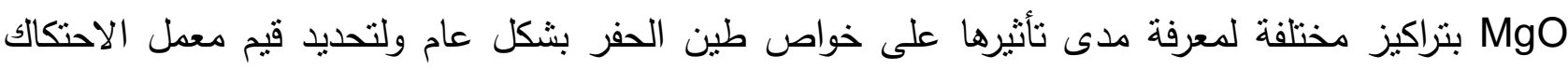

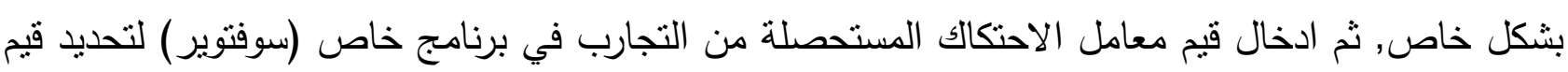

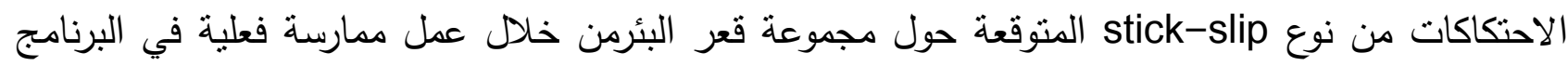

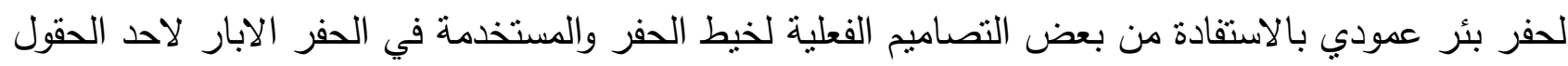
العراقية. - مان.

ان الهدف من هذا العمل هو للحصول على نماذج طين حفر تقلل او تمنع حدوث ظاهرة الالتصاق والانزلاق التي يؤدي حدوثها الى مشاكل حفر عديدة ك : تلف الحافرة وملحفاتها, التصاق الانابيب, عدم استقرار جدار البئر , انخفاض معدل الاختراق.

نجحت دراستتا في ايجاد تراكيز من النانو MgO حققت انخفاض في جهد الاحنكاك (Torque) كالاتي:

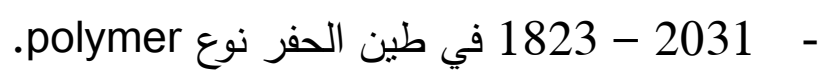

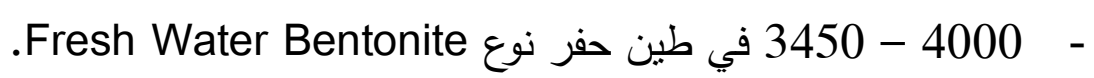

علما ان النتائج اعلاه كانت متزامنة مع مواصفات طين الحفر ضمن المدى المقبول لتحقيق اهداف سائل

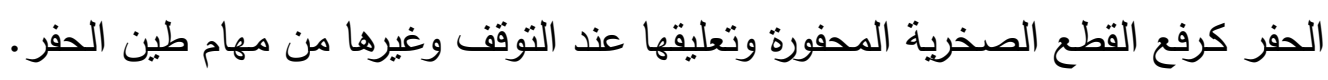

